\title{
LOGISTICS PROJECTS BASED ON RADIO FREQUENCY IDENTIFICATION: MULTI-CRITERIA ASSESSMENT OF BRAZILIAN AIRCRAFT INDUSTRY
}

\author{
Jefferson Inácio de Castro ${ }^{*}$, Jorge Muniz $\mathrm{Jr}^{2}$, \\ Ednilson Bernardes ${ }^{3}$ and Claudemir Leif Tramarico ${ }^{4}$
}

Received October 24, 2020 / Accepted July 30, 2021

\begin{abstract}
The purpose of this paper is to investigate the prioritization of Radio Frequency Identification Technology (RFID) logistics projects in a developing economy. This paper adopts a Multi-Criteria DecisionMaking (MCDM) method to assess RFID logistics projects. The study examines the use of RFID in the Brazilian aerospace industry and contributes to both the RFID and MDCA literature. The main contribution of this article is to present RFID applications in industrial processes and their strategic approaches, seeking to improve the efficiency, flexibility and the inventory visibility. The approach proposed a decision process to assess RFID logistics projects in the Brazilian aeronautics industry.
\end{abstract}

Keywords: analytic hierarchy process, aerospace industry, logistics management, radio frequency technology.

\section{INTRODUCTION}

Studies in science and technology have grown over the last past three decades by researchers, for Radio Frequency Identification (RFID) was no different. RFID is a type of passive wireless technology that allows for tracking or matching of an item or individual in real time for many applications or depends on particular situations such as tracking products by manufacturers and

\footnotetext{
*Corresponding author

${ }^{1}$ Universidade Estadual Paulista Júlio de Mesquita Filho Faculdade de Engenharia, Campus de Guaratinguetá. Av. Dr. Ariberto Pereira da Cunha, 333, 12516-410 Guaratinguetá, SP, Brazil - E-mail: jeffidcastro@gmail.com https://orcid.org/0000-0002-9276-9516

${ }^{2}$ Universidade Estadual Paulista Júlio de Mesquita Filho Faculdade de Engenharia, Campus de Guaratinguetá. Av. Dr. Ariberto Pereira da Cunha, 333, 12516-410 Guaratinguetá, SP, Brazil - E-mail: jorge.muniz@unesp.br https://orcid.org/0000-0003-3496-0256

3 West Virginia University, 1601 University Avenue, PO Box 6025, Morgantown, WV 26506, USA - E-mail: ednilson.bernardes@mail.wvu.edu - https://orcid.org/0000-0002-6782-7323

${ }^{4}$ Universidade Estadual Paulista Júlio de Mesquita Filho Faculdade de Engenharia, Campus de Guaratinguetá. Av. Dr. Ariberto Pereira da Cunha, 333, 12516-410 Guaratinguetá, SP, Brazil - E-mail: claudemir.tramarico@unesp.br https://orcid.org/0000-0001-9348-939
} 
distributors. RFID is often seen as a prerequisite for the Internet of Things to track, to organize, to optimize and also for high operational and strategic in terms of increased efficiency and effectiveness, and better decision-making.

Emerging economies have grown in importance as destinations for new markets and as new destinations in global value chains. However, they typically have an institutional environment characterized by unstable economic systems and restrictions on capital (Prasad \& Babbar, 2000), cultural differences (Pagell et al., 2005), and considerable degree of uncertainty (Prasad \& Tata, 2010; Lorentz \& Ghauri, 2010), all of which impacts decisions related to investments in supply chain projects based on new technologies.

While the extant literature has discussed the benefits and potential drivers of RFID implementation, it has focused primarily on issues and projects from the perspective of developed economies. Therefore, considering the growing importance of emerging economies and their unique environment, it is crucial to explore how organizations prioritize RFID projects in emerging markets even applying traditional methodologies for assessing return on investment the company's need for more detailed information to understand the contribution of the RFID system in the planning and configuration on industrial processes.

Specifically, there is a need for an assessment that assists in identifying, deciding on, and prioritizing RFID implementation projects. In this study, logistics projects related to RFID in the Brazilian aerospace industry were examined. This choice allows us to understand the selection and prioritization of projects and the use of the RFID technology in a supply chain of an emerging economy.

The recent RFID literature indicates research opportunities about its influence in different production lines such as increase system accuracy in location based on technology application within inventory management (Moon et al., 2018); improve RFID benefits related to logistic processes automation of the main typologies handled in the warehouse (Giusti et al., 2019); built scenarios of logistics process flows for tagging and tracking of designated assets (Moatari-Kazerouni $\&$ Bendavid, 2017). This article explores these opportunities as contributions to: (i) propose an assessments tool of logistics projects based on RFID technology to the aeronautical industry, (ii) support decision-makers to select projects to logistics applications.

Multi-Criteria Decision Making (MCDM) is relevant to decision-making and problem-solving, as it allows the objective evaluation of multiple conflicting criteria and alternatives. MCDM studies have been applied in several fields, such as Management, Economics, Informatics, Mathematics, and Psychology (Köksalan et al., 2011). Analytic Hierarchy Process (AHP) is a MCDM method and is commonly used to assess strategy, performance, and ranking alternatives in supply chain and logistics (Sipahi \& Timor, 2010). AHP, as a multi-criteria decision method, decomposes complex decision-making problems (i.e., with multiple judgments at different levels of criteria and alternatives) into sub-problems with hierarchical levels (see for example Muniz Jr. et al., 2019). Other motivation to AHP application is based on coherent quantitative treatment about qualitative judgements of logistic projects criteria. 
The paper is structured as follows. We will first review the background literature for RFID and identify the main attributes to implement RFID projects. In method, we introduce AHP approach and its application to project prioritization and report the main findings. Finally, we conclude with discussion and conclusions.

\section{LITERATURE REVIEW}

RFID application has received considerable attention in recent years by researchers and practitioner for evaluated the effectiveness enabled building information modelling, for tracking and tracing of work in process, for performance testing and productivity measure, for inventory management, for developed workflow, for improved business processes, for research in building materials, for developed an algorithm to create virtual queues, for developed application to share information on public transport. Table 1 summarizes the main RFID approaches and methods proposed of the most cited articles.

\subsection{Radio frequency identification}

RFID is an automatic wireless identification and data capture technology that establishes the identity of objects within a specified radio frequency range through radio waves without human intervention or data entry (Chong \& Chan, 2012; Müller-Seitz et al., 2009). It has in common with bar codes the storage of serial numbers and related product information on a microchip (Ngai et al., 2008). However, the RFID technology allows the tracking, storage, and communication of product information in the supply chain beyond the line-of-sight and has higher data storage capacity (Wamba \& Ngai, 2012; Chong et al., 2015). The technology consists of a tag that stores and transmits information, a reader that wirelessly sends data from the tag to a backend database, and a middleware that filters data from readers to avoid information overload and assure accuracy.

The interest in RFID flourished after Walmart announced that its top 100 suppliers should attach RFID tags to their pallets and cases beginning in 2005 (Hunt et al., 2007; Shin \& Eksioglu, 2015). More recently, Walmart has been focusing on item-level RFID tagging (Roberti, 2014). Similar to the U.S., retail firms from various European countries started implementing RFID around the same time Walmart did (Shin \& Eksioglu, 2015). Prior research on the adoption of RFID in the retail industry suggests that operational efficiency and cost savings are the two main benefits of the technology. Specifically, the benefits include inventory accuracy, security, visibility, productivity, and labor cost savings among others (Bhattacharya, 2012; Fan et al., 2015; Gaukler, 2010; Hardgrave et al., 2013; De Kok et al., 2008; Rekik et al., 2008; Sarac et al., 2010; Senauer \& Seltzer, 2010; Shin \& Tucci, 2015; Shin \& Eksioglu, 2015; Thiel et al., 2010; Tsai et al., 2010; Zhu et al., 2012). While there are seemingly many potential benefits from the adoption of RFID in retail, there are also several potential hurdles.

Prior research indicates that economic, technical, and organizational considerations are potential deterrents of the adoption of RFID technology in supply chains. Issues include the lack of a 
Table 1 - The most cited articles according number of citations.

\begin{tabular}{|c|c|c|c|c|c|}
\hline \# & Most cited articles & Journal & Proposed RFID approach & Method & Authorship \\
\hline 1 & $\begin{array}{l}\text { Integrating RFID and } \\
\text { BIM technologies for } \\
\text { mitigating risks and } \\
\text { improving schedule } \\
\text { performance of } \\
\text { prefabricated house } \\
\text { construction }\end{array}$ & $\begin{array}{l}\text { Journal of } \\
\text { Cleaner } \\
\text { Production }\end{array}$ & $\begin{array}{l}\text { Application of RFID } \\
\text { enabled building } \\
\text { information modelling } \\
\text { platform }\end{array}$ & $\begin{array}{l}\text { Case } \\
\text { study }\end{array}$ & $\begin{array}{l}\text { LI et al. } \\
(2017)\end{array}$ \\
\hline 2 & $\begin{array}{l}\text { An RFID-based tracking } \\
\text { system for denim } \\
\text { production processes }\end{array}$ & $\begin{array}{l}\text { The International } \\
\text { Journal of } \\
\text { Advanced } \\
\text { Manufacturing } \\
\text { Technology }\end{array}$ & $\begin{array}{l}\text { Implementation of RFID } \\
\text { including design, } \\
\text { configuration and } \\
\text { deployment }\end{array}$ & $\begin{array}{l}\text { Case } \\
\text { study }\end{array}$ & $\begin{array}{l}\text { Oner et al. } \\
\text { (2017) }\end{array}$ \\
\hline 3 & $\begin{array}{l}\text { RFID-Aided Tracking } \\
\text { System to Improve Work } \\
\text { Efficiency of Scaffold } \\
\text { Supplier: Stock } \\
\text { Management in } \\
\text { Australasian Supply } \\
\text { Chain }\end{array}$ & $\begin{array}{l}\text { Journal of } \\
\text { Construction } \\
\text { Engineering and } \\
\text { Management }\end{array}$ & $\begin{array}{l}\text { Application of } \\
\text { RFID-Aided tracking } \\
\text { system }\end{array}$ & $\begin{array}{l}\text { Case } \\
\text { study }\end{array}$ & $\begin{array}{l}\text { Moon et al. } \\
\text { (2018) }\end{array}$ \\
\hline 4 & $\begin{array}{l}\text { Monitoring on-shelf } \\
\text { availability, out-of-stock } \\
\text { and product freshness } \\
\text { through RFID in the fresh } \\
\text { food supply chain }\end{array}$ & $\begin{array}{l}\text { International } \\
\text { Journal of RF } \\
\text { Technologies }\end{array}$ & $\begin{array}{l}\text { Implementation of RFID } \\
\text { in a fresh food supply } \\
\text { chain. }\end{array}$ & $\begin{array}{l}\text { Case } \\
\text { study }\end{array}$ & $\begin{array}{l}\text { Bottani et al. } \\
(2017)\end{array}$ \\
\hline 5 & $\begin{array}{l}\text { Using look-ahead plans to } \\
\text { improve material flow } \\
\text { processes on construction } \\
\text { projects when using BIM } \\
\text { and RFID technologies }\end{array}$ & $\begin{array}{l}\text { Construction } \\
\text { Innovation }\end{array}$ & $\begin{array}{l}\text { Propose a workflow using } \\
\text { RFID and building } \\
\text { information modelling }\end{array}$ & $\begin{array}{l}\text { Simula- } \\
\text { tion }\end{array}$ & $\begin{array}{l}\text { Chen et al. } \\
(2020)\end{array}$ \\
\hline 6 & $\begin{array}{l}\text { Improving logistics } \\
\text { processes of surgical } \\
\text { instruments: case of RFID } \\
\text { technology }\end{array}$ & $\begin{array}{l}\text { Business Process } \\
\text { Management } \\
\text { Journal }\end{array}$ & $\begin{array}{l}\text { Implementation of RFID } \\
\text { to improve the traceability } \\
\text { of surgical instruments in } \\
\text { a hospital environment }\end{array}$ & $\begin{array}{l}\text { Case } \\
\text { study }\end{array}$ & $\begin{array}{l}\text { Moatari- } \\
\text { Kazerouni \& } \\
\text { Bendavid } \\
(2017)\end{array}$ \\
\hline 7 & $\begin{array}{l}\text { Building materials } \\
\text { management system based } \\
\text { on RFID technology }\end{array}$ & $\begin{array}{l}\text { International } \\
\text { Journal of RF } \\
\text { Technologies }\end{array}$ & $\begin{array}{l}\text { Propose and implement a } \\
\text { closed-loop information } \\
\text { flow to facilitate building } \\
\text { materials based on RFID }\end{array}$ & $\begin{array}{l}\text { Case } \\
\text { study }\end{array}$ & $\begin{array}{l}\text { Ren \& Li } \\
(2018)\end{array}$ \\
\hline 8 & $\begin{array}{l}\text { State of the art of } \\
\text { item-level RFID } \\
\text { deployments in fashion } \\
\text { and apparel retail }\end{array}$ & $\begin{array}{l}\text { International } \\
\text { Journal of RF } \\
\text { Technologies }\end{array}$ & $\begin{array}{l}\text { Present a literature } \\
\text { overview of the current } \\
\text { adoption of RFID } \\
\text { technology in fashion and } \\
\text { apparel retail }\end{array}$ & $\begin{array}{l}\text { Content } \\
\text { analysis } \\
\text { study }\end{array}$ & $\begin{array}{l}\text { Cilloni et al. } \\
\text { (2019) }\end{array}$ \\
\hline 9 & $\begin{array}{l}\text { Introducing a new support } \\
\text { model for access control } \\
\text { of road cargo vehicles at } \\
\text { Brazilian ports through } \\
\text { Radio Frequency } \\
\text { Identification Technology } \\
\text { (RFID) }\end{array}$ & $\begin{array}{l}\text { Brazilian Journal } \\
\text { of Urban } \\
\text { Management }\end{array}$ & $\begin{array}{l}\text { Propose a model for } \\
\text { access control and } \\
\text { optimization of cargo } \\
\text { loading at ports based on } \\
\text { RFID }\end{array}$ & $\begin{array}{l}\text { Simula- } \\
\text { tion }\end{array}$ & $\begin{array}{l}\text { Bittencourt } \\
\text { et al. (2018) }\end{array}$ \\
\hline 10 & $\begin{array}{l}\text { Sharing information on } \\
\text { public transport with } \\
\text { RFID and NFC } \\
\text { technologies: an } \\
\text { application proposal }\end{array}$ & $\begin{array}{l}\text { Brazilian Journal } \\
\text { of Urban } \\
\text { Management }\end{array}$ & $\begin{array}{l}\text { Propose an application of } \\
\text { smart bus using near field } \\
\text { communication and RFID }\end{array}$ & $\begin{array}{l}\text { Case } \\
\text { study }\end{array}$ & $\begin{array}{l}\text { Nassar \& } \\
\text { Vieira (2017) }\end{array}$ \\
\hline
\end{tabular}


global standard, the high cost of the investment and uncertainty of the return, the need of an existing information technology infrastructure, limited understanding about its business value and social issues (De Marco et al., 2012; Gaukler, 2011; Sarac et al., 2010; Thiesse et al., 2011; Whitaker et al., 2007; Zhu et al., 2012). Small and medium businesses, in particular, perceive the implementation of RFID technology as risky and cost-ineffective (Lee \& Lee, 2010; Lee \& Özer, 2007; Shin \& Eksioglu, 2015).

While the implementation of RFID technology and its corresponding research attention became initially prominent in the retail supply chain, the use of the technology is now widespread. For instance, more recently, there has been growing interest in understanding the adoption of RFID in the health care supply chain. In addition to inventory management and cost reduction benefits, the technology in this industry can contribute towards error reduction and better control of patient records (Chong et al., 2015; Chong \& Chan, 2012; Lee \& Shim, 2007). RIFD can be used across the various stages of the supply chain, including warehouses, transportation, distribution centers, manufacturing, and other logistics applications (Yin et al., 2009). Besides, organizations can use it for purposes that range from supporting the Internet of Things and harvesting big data to achieving competitive advantage (Fan et al., 2015; Hazen et al., 2014; Hazen \& Byrd 2012; Ray et al., 2014).

In the aerospace supply chain, Original Equipment Manufacturers (OEM) have been using RFID technology to improve operational efficiency and control. The U.S. company Boeing uses RFID technology on the parts of the 787 model to improve configuration management, help airline operators reduce operational costs, and track parts (Ataebiz, 2010). In 2006, Airbus, a consortium of various European aerospace companies, started implementing RFID technology. Initially, Airbus explored RFID technology to streamline supply chain tracking capabilities by automating data entry across logistics processes. Subsequently, Airbus used the technology to improve the manufacturing, assembly, and global transportation, as well as in-service processes and support operations (Wasserman, 2007). Airbus separates RFID applications into flyable, for product application consisting of tags attached to parts and components in the final aircraft, and non-flyable, for process applications where the tag is not permanently attached to parts and components in the in-service aircraft (Airbus, 2014). Airbus was the first company in the aerospace industry to adopt RFID on a program (A350 XWB) to track parts. The non-flyable projects focus on logistics, distribution, manufacturing, and assembly.

While there have been significant advancements in our understanding of the adoption of RFID technology in supply chain projects across many industries, less is known about the selection of projects for the application of the technology in the context of the emerging Brazilian economy. The literature reveals few cases of RFDI in supply chains in Brazil. In the aerospace industry, there has been considerable progress in projects based on RFID use in the supply chain. However, most of the advancements have been made around the supply chains of the two largest aerospace industries, Boeing and Airbus, in the North hemisphere. Therefore, it becomes crucial to explore how RFID projects are prioritized in the aerospace industry of an emerging market. Specifically, there is a need for a framework that assists in identifying, deciding on, and prioritizing RFID im- 
plementation projects. The Brazilian aerospace industry is the largest in the southern hemisphere, and its leading OEM was elected the most innovative company in Brazil, 2016.

Table 2 presents a summary of the RFID projects in logistics. In Table 2, the project Tracking Loads Along the Supply Chain (A) is indicated by the authors as a proposal for monitoring materials in the logistics processes, i.e., they propose to use the technology to follow the material along the stages of the supply chain. Lee \& Lee (2010), in their research with executives, explored this subject and pointed out that this application improves accuracy, visibility, cycle management, and operational efficiency. However, Wu et al. (2006) highlight the challenges of that implementation due to the limitations of the technology itself, standardization, national regulations, and implementation costs. The complexity of this implementation is proportional to the complexity and number of links in the chain. Strategically, Attaran (2007) indicates that the technology can enhance customer relationship and enable a competitive differential. Besides, it reduces losses in the process, enable process automation, and reduces errors, among other benefits.

The project Automatic Inventory (B) consists of verifying components along the stages of the process. Rekik et al. (2008) propose the use of RFID to reduce inventory inaccuracy. Lyu et al. (2009), reporting on a model applying RFID for quality assurance in a cable company and in an energy company, indicate that RFID application in inventory helps increase equipment efficiency, improve security, and simplify processes. RFID supports Warehouse Management Systems WMS, ERP.

Lin et al. (2011), seeking to identify new functions to the RFID technology, propose that the project vehicles/assets/equipment identification (C) addresses seven RFID functions. Out of these seven functions, some are: process integration, battery recharging control, access control, and vehicle rental. Vehicles, assets, and equipment identification augment the use of the technology to include maintenance management and item proprietary data loading, such as last maintenance date, next maintenance date, and last inventory. As such, this application provides the equipment, asset, or vehicle with a fixed and unique identification where data recorded or triggered along the item's life cycle.

The project Reverse Logistics (D) is the application of RFID technology in the stage of return within the process flow. Trappey et al. (2010) indicate that this process includes the direct return of items to their manufacturers, indirect return of items to their repair shops, individual items return in small quantities, product change, among others. Decision making, cycle time, waiting time, and accuracy were some of the improvements from the model presented. Dai et al. (2015) indicate that product traceability can be enabled and improve supply chain performance in product safety, product recall, and reverse logistics.

Decision Support to Project/Predictive Logistics (E) is a project that makes use of information enhanced by RFID to help the decision-making process, improving expected results, and reducing risks. Ozguven and Ozbay (2015) use RFID in a model to predict the inventory level of emergency suppliers. In this case, the authors used the RFID information in a disaster situation to decide each stage of the disaster operation. 
Table 2 - RFID projects in logistics.

\begin{tabular}{|c|c|c|c|}
\hline Project & & Definition & Reference \\
\hline $\mathbf{A}$ & Tracking loads along the supply chain & $\begin{array}{l}\text { Location and staging information } \\
\text { among supply chain }\end{array}$ & $\begin{array}{l}\text { Attaran (2007) } \\
\text { Bose \& Yan (2011) } \\
\text { Lee \& Lee (2010) } \\
\text { Lyu et al. (2009) } \\
\text { Sarac et al. (2010) } \\
\text { Trebar et al. (2015) } \\
\text { Wu et al. (2006) } \\
\text { Zhou (2009) }\end{array}$ \\
\hline $\mathbf{B}$ & Automatic Inventory & $\begin{array}{l}\text { Automatic verification during the } \\
\text { process collecting data and counting } \\
\text { products }\end{array}$ & $\begin{array}{l}\text { Dutta et al. (2007) } \\
\text { Lee \& Chan (2009) } \\
\text { Lee et al. (2004) } \\
\text { Lin et al. (2011) } \\
\text { Lyu et al. (2009) } \\
\text { Nativi \& Lee (2012) } \\
\text { Ngai et al. (2007) } \\
\text { Ozguven \& Ozbay (2015) } \\
\text { Rekik et al. (2008) } \\
\text { Wang et al. (2008) }\end{array}$ \\
\hline $\mathbf{C}$ & Vehicles/assets/equipment identification & $\begin{array}{l}\text { Identify and control vehicles, asset in } \\
\text { general and equipment in the process }\end{array}$ & $\begin{array}{l}\text { Attaran (2007) } \\
\text { Lin et al. (2011) } \\
\text { Lyu et al. (2009) }\end{array}$ \\
\hline D & Reverse logistics & $\begin{array}{l}\text { Identify and control products or } \\
\text { packages in a reverse logistics process }\end{array}$ & $\begin{array}{l}\text { Dai et al. (2015) } \\
\text { Lee \& Chan (2009) } \\
\text { Nativi \& Lee (2012) } \\
\text { Trappey et al. (2010) }\end{array}$ \\
\hline $\mathbf{E}$ & $\begin{array}{l}\text { Decision support/predictive logistics } \\
\text { (risk and uncertainty management in the } \\
\text { process) }\end{array}$ & $\begin{array}{l}\text { Use data and RFID information } \\
\text { available to support decision in a supply } \\
\text { chain }\end{array}$ & $\begin{array}{l}\text { Attaran (2007) } \\
\text { Dutta et al. (2007) } \\
\text { Nativi \& Lee (2012) } \\
\text { Ozguven \& Ozbay (2015) } \\
\text { Trappey et al. (2010) }\end{array}$ \\
\hline $\mathbf{F}$ & Pallets incoming (dense readings) & $\begin{array}{l}\text { Read a huge quantity of boxes in a pallet } \\
\text { avoiding unpacking/deconsolidation } \\
\text { process }\end{array}$ & $\begin{array}{l}\text { Attaran (2007) } \\
\text { Dutta et al. (2007) } \\
\text { Ngai et al. (2007) } \\
\text { Sarac et al. (2010) } \\
\text { Véreonneau \& Roy (2009) }\end{array}$ \\
\hline G & $\begin{array}{l}\text { Industrial process automation (in-out } \\
\text { portals) } \\
\text { Incoming/Storage/Inventory/ } \\
\text { Segregation/Expedition }\end{array}$ & $\begin{array}{l}\text { Automatic status and location definition } \\
\text { using RFID process }\end{array}$ & $\begin{array}{l}\text { Attaran (2007) } \\
\text { Daí \& Tseng (2012) } \\
\text { Hellström \& Wiberg (2010) } \\
\text { Lim et al. (2013) } \\
\text { Ngai et al. (2007) } \\
\text { Ustundag \& Tanyas (2009) } \\
\text { Véreonneau \& Roy (2009) }\end{array}$ \\
\hline $\mathbf{H}$ & Process materials recycling management & $\begin{array}{l}\text { Identify and control waste-controlled } \\
\text { materials process }\end{array}$ & $\begin{array}{l}\text { Attaran (2007) } \\
\text { Bose \& Yan (2011) }\end{array}$ \\
\hline I & High added value pieces management & $\begin{array}{l}\text { Identify and control high value asset in } \\
\text { the process }\end{array}$ & Ngai et al. (2007) \\
\hline $\mathbf{J}$ & $\begin{array}{l}\text { Automatic replacement - Supply Chain } \\
\text { Pull Systems/ Support to JIT }\end{array}$ & $\begin{array}{l}\text { Automatic replenishment requisition } \\
\text { using RFID information }\end{array}$ & $\begin{array}{l}\text { Attaran (2007) } \\
\text { Wang et al. (2008) }\end{array}$ \\
\hline $\mathbf{K}$ & $\begin{array}{l}\text { Incoming with item } \\
\text { segregation/separation }\end{array}$ & $\begin{array}{l}\text { Identify, select and sort material in } \\
\text { receiving process }\end{array}$ & Lee \& Chan (2009) \\
\hline $\mathbf{L}$ & In-truck inventory & $\begin{array}{l}\text { Monitor material during transportation } \\
\text { process }\end{array}$ & $\begin{array}{l}\text { Lee \& Chan (2009) } \\
\text { Trebar et al. (2015) }\end{array}$ \\
\hline M & $\begin{array}{l}\text { Information traffic via RFID } \\
\text { (component/process data) without } \\
\text { Electronic Data Interchange (EDI) }\end{array}$ & $\begin{array}{l}\text { Share information among supply chain } \\
\text { using RFID storage capability }\end{array}$ & $\begin{array}{l}\text { Lee \& Chan (2009) } \\
\text { Ngai et al. (2007) }\end{array}$ \\
\hline
\end{tabular}


Pallets' identification within the process with incoming automation provides improvements in productivity and error reduction. Dutta et al. (2007) point out that, from the moment that multiple labels can be read simultaneously, shifting away from having to read one by one manually, and without having to handle objects, one can have a significant labor cost reduction. Sarac et al. (2010) indicated a decrease in 16\% error in items out of stock and inventories in Wal-Mart by RFID technology. The Project Incoming Pallets (F) RFID technology to identify incoming pallets during the inbound logistics stage. Véreonneau \& Roy (2009) indicate that only one link in the chain does not justify the cost added to the process. The incoming item stage, in this case, represents the point when responsibility is transferred from one party to the other.

The project industrial process automation (G) is explored by Lim et al. (2013). The authors review the application of RFID technology within warehouse processes. Considering the processes of receiving, storage, picking, and expedition, mentioned by the authors, the most significant number of implementations happen during the incoming stage, as presented in Figure 1.

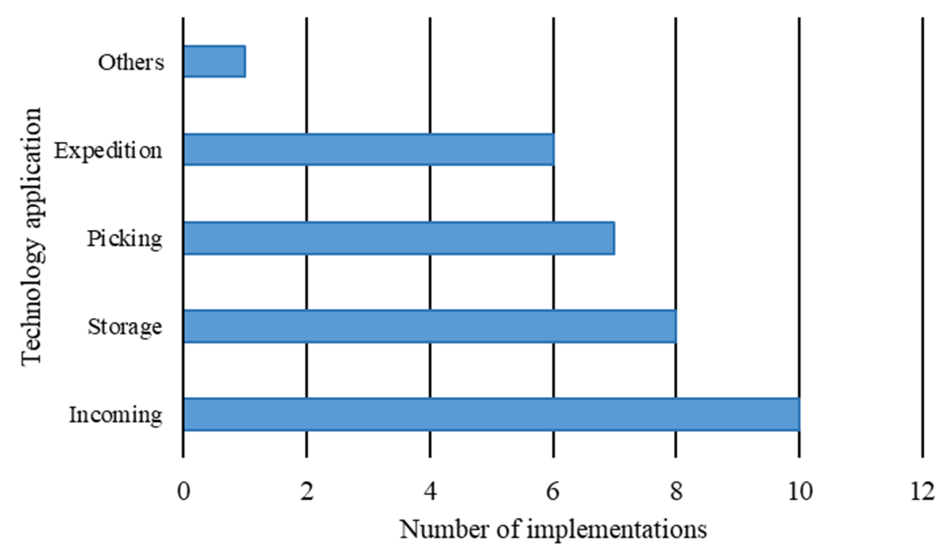

Figure 1 - Warehouse RFID implementations. (Adapted from Lim et al. 2013).

Ustundag \& Tanyas (2009) also point out the RFID application in the incoming and expedition stages with the installation of warehouse portals. The project aimed at reducing costs in the aspects of operational efficiency, accuracy, visibility, and security. Hellström \& Wiberg (2010) also make the association between warehouse portals and industrial process automation. Their analytical model compares the use of RFID with manual data to upgrade using bar code to improving inventory accuracy in an automobile manufacturer. The results meant that RFID technology was eliminating the manual data entry or barcode; this is the first step to improving inventory accuracy.

Bose \& Yan (2011) reviewed 13 projects using RFID technology focusing on Green IT. Five of these projects focus on recycling. The Recycling Materials Management Project $(\mathrm{H})$ reduce $\mathrm{CO} 2$ and reuse related to packaging. The recycling process gives the right destination to materials, assuring their recycling or reuse. 
The high Value-Added Pieces Management (I) is based on segregating high value-added items for RFID application and items management along the logistics processes. Ngai et al. (2007) point out this application as strategic for assessing its benefits and ROI calculation. The benefits mentioned are related to components inventory reduction and component used by more than one department as well as the benefits of labor costs and cycle reduction.

According to Shingijutsu (2014), for the implementation of a successful JIT system, it is necessary to know what, how much, and when an item is needed. The best way to implement these elements is to ensure that the next process has only what is necessary. The Automatic Repositions Project (J) uses RFID technology to generate signals along the process, informing the previous process about supply demands. Figure 2 illustrates how this application would look like, for example, using portals along the process and sharing information among them during flow material.

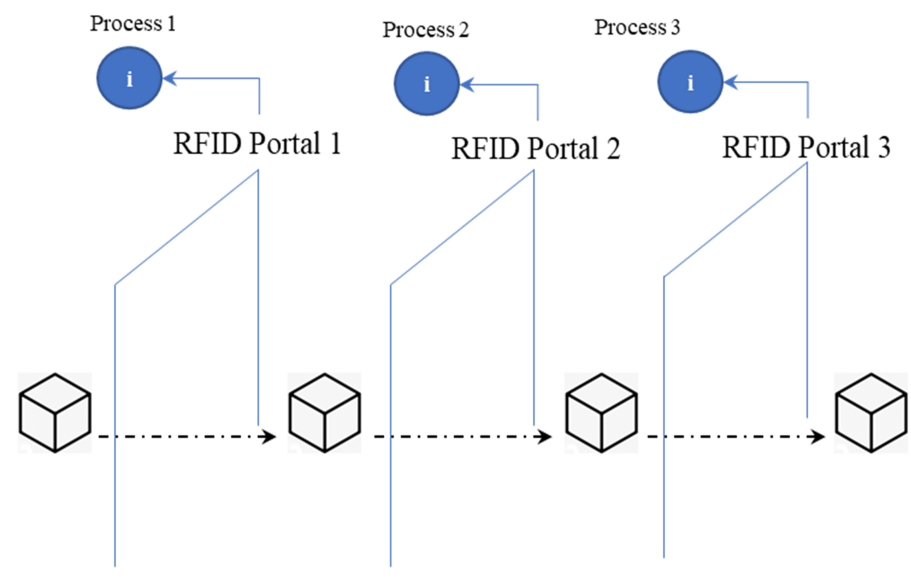

Figure 2 - RFID automatic repositions project.

Wang et al. (2008) established an automatic reposition simulation function, from RFID, with a pull system in the 17 inches TFT-LCD monitors supply box. The flowchart of such application is exhibited in Figure 3.

In the incoming sector, RFID labels can be used to segregate items according to business rules, as in the Incoming Project with Item Segregation/Separation (K). Lee \& Chan (2009) state that such segregation, for example, can be used in the receiving of a repair center to reduce manual work and waste.

In Truck Items Inventory Project (L), Lee \& Chan (2009) mentioned the objective of knowing the composition of a truck along its traffic route all the time. This way, it is possible to determine an efficient route. In addition, as applied by Trebar et al. (2015) in a fish transportation process, monitoring temperature conditions, materials can be controlled using RFID registering data and/or creating events. 


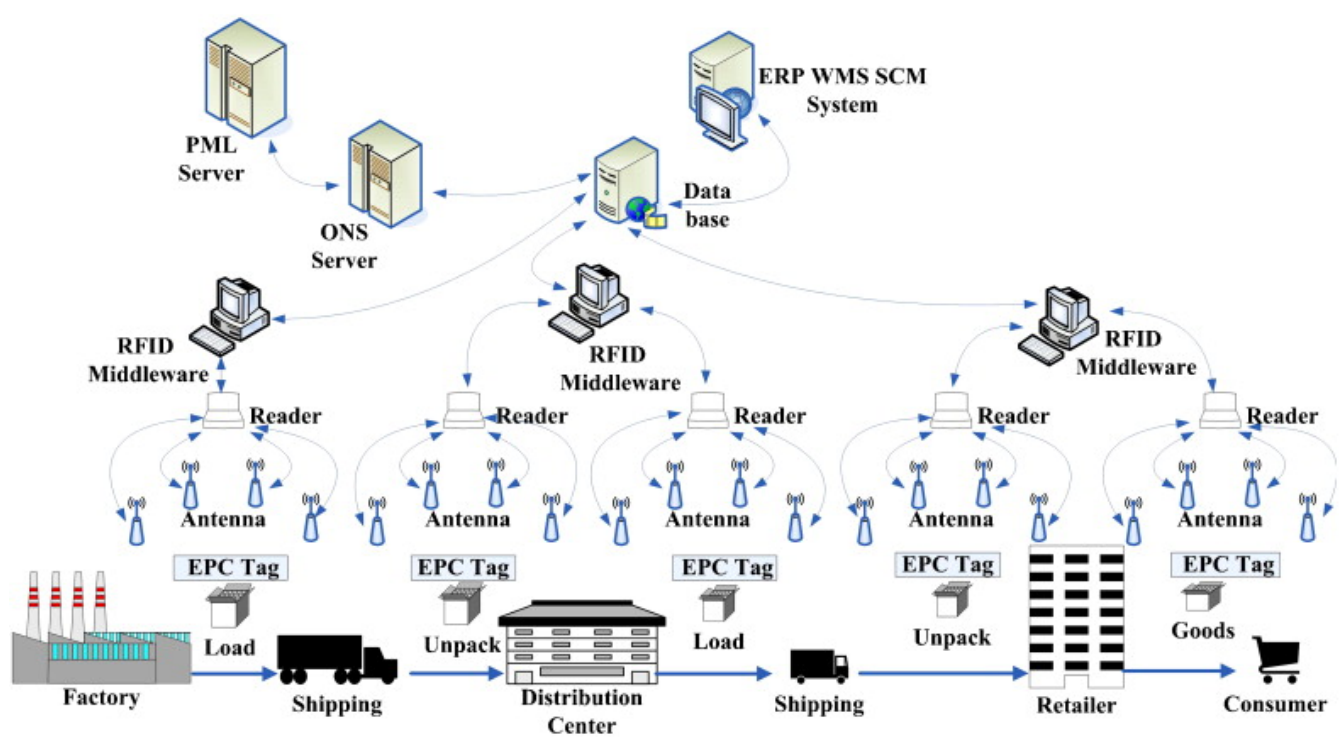

Figure 3 - Flowchart of RFID in SCM (Wang et al., 2008).

Ngai et al. (2007) indicate that instead of creating a logical infrastructure among the processes' links, it is possible to activate an RFID system in which the labels along the process transfer all information. This action promotes broad integration with fewer infrastructure costs, which is the aspect that RFID Traffic Information (M) intends to solve. It has the purpose of transitioning information across the supply chain and within the industrial processes of each participant in the network.

\subsection{Attributes from literature review to implement RFID projects}

The literature review indicated potential benefits and hurdles associated with the adoption of RFID technology in supply chains. As such, attributes that characterize benefits are those that motivate possible adoption, while those that describe hurdles are perceived as impediments and constrain it is adoption.

The attribute cost captures the expenditure acquiring the information based on the technology (Wang et al., 2008; Attaran, 2007); buying the technology (hardware and service); and maintenance, upgrade, and support (Lee \& Lee, 2010). The latter can be classified in hardware, software, development, training, and service (Lee \& Lee, 2010).

The attribute operational efficiency is related to work reduction such as pallet identification avoiding unitary parts records (Lee \& Lee, 2010; Sarac et al. 2010). Véreonneau \& Roy (2009) discussed benefits, cost, and applications. This attribute does not consider lead time.

Information is associated with the availability of information along the process. It must address the customer need, and it must be available along the supply chain (Attaran, 2007). It is applied 
to reverse logistics of recycled materials to increase process visibility within the supply chain. It increases the return of these materials in the process by $87 \%$ in average and reduces the cost by $19 \%$. Furthermore, it allows real-time monitoring, a continuous review, information sharing in the supply chain, and visibility between inventories, helping the supply chain to quickly adapt to system changes (Nativi and Lee, 2012). However, Véreonneau and Roy (2009) indicate that this can also be enhanced by a sound bar code system supported by a competent Warehouse Management System (WMS).

Table 3 presents the attributes considered in this research.

Table 3 - RFID projects attributes.

\begin{tabular}{|c|c|c|c|}
\hline Attribute & & Definition & Reference \\
\hline 1 & Cost & $\begin{array}{l}\text { This attribute has definitions: the cost to implement } \\
\text { RFID technology as a challenge and saving in you } \\
\text { process applying the technology }\end{array}$ & $\begin{array}{l}\text { Attaran (2007) } \\
\text { Dai et al. (2015) } \\
\text { Lee \& Chan (2009) } \\
\text { Lee Lee (2010) }\end{array}$ \\
\hline 2 & $\begin{array}{l}\text { Operational } \\
\text { efficiency }\end{array}$ & $\begin{array}{l}\text { This attribute is related to productivity. The relation } \\
\text { between resource and production. }\end{array}$ & $\begin{array}{l}\text { Dutta et al. (2007) } \\
\text { Lee \& Chan (2009) } \\
\text { Véreonneau \& Roy (2009) }\end{array}$ \\
\hline 3 & Information & $\begin{array}{l}\text { Level of visibility, tracking and information sharing } \\
\text { among the supply chain. }\end{array}$ & $\begin{array}{l}\text { Zhou (2009) } \\
\text { Dai et al. (2015) } \\
\text { Lim et al. (2013) } \\
\text { Lee \& Lee (2010) } \\
\text { Nativi \& Lee (2012) }\end{array}$ \\
\hline 4 & Quality & $\begin{array}{l}\text { Quantity of errors in the process and process } \\
\text { reliability. }\end{array}$ & $\begin{array}{l}\text { Daí \& Tseng (2012) } \\
\text { Dutta et al. (2007) } \\
\text { Hellström \& Wiberg (2010) } \\
\text { Lim et al. (2013) } \\
\text { Rekik et al. (2008) } \\
\text { Ustundag \& Tanyas (2009) } \\
\text { Wang et al. (2008) }\end{array}$ \\
\hline 5 & Technology & $\begin{array}{l}\text { Regulations and standards available, knowledge of } \\
\text { the technology and their benefits and restrictions; } \\
\text { equipment and installation required to apply RFID in } \\
\text { the process. }\end{array}$ & $\begin{array}{l}\text { Bose \& Yan (2011) } \\
\text { Lee \& Chan (2009) } \\
\text { Lim et al. (2013) } \\
\text { Lee \& Lee (2010) } \\
\text { Ngai et al. (2007) } \\
\text { Wu et al. (2006) }\end{array}$ \\
\hline 6 & $\begin{array}{l}\text { Customer } \\
\text { satisfaction }\end{array}$ & $\begin{array}{l}\text { The level of satisfaction of your customer in the } \\
\text { process. }\end{array}$ & $\begin{array}{l}\text { Lim et al. (2013) } \\
\text { Ngai et al. (2007) }\end{array}$ \\
\hline 7 & Cycle Time & $\begin{array}{l}\text { This attribute is the time spend in the process } \\
\text { including idle time and inventory process. }\end{array}$ & $\begin{array}{l}\text { Sarac et al. (2010) } \\
\text { Trappey et al. (2010) }\end{array}$ \\
\hline 8 & Safety & $\begin{array}{l}\text { Include reliability, integrity and availability. Data } \\
\text { confidentiality and cargo integrity is related to this } \\
\text { attribute. }\end{array}$ & $\begin{array}{l}\text { Ngaia et al. (2008) } \\
\text { Trappey et al. (2010) }\end{array}$ \\
\hline 9 & Sustainability & $\begin{array}{l}\text { Environmental, social and economic aspects involved } \\
\text { in the process. }\end{array}$ & $\begin{array}{l}\text { Bose \& Yan (2011) } \\
\text { Lim et al. (2013) } \\
\text { Nativi \& Lee (2012) }\end{array}$ \\
\hline
\end{tabular}


The attribute quality relates to error due to human failure and process reliability due to process automation. Ustundag, \& Tanyas (2009) added process security to reliability because deviations can also happen due to pilferage. Rekik et al. (2008) point that variation of products reduces distributor performance, and, as a consequence, they proposed a model considering error elimination and process reliability increase. They propose the extension of this model, making the logical verification of the system with the real item availability in inventory. Reliability is confirmed by Dai \& Tseng (2012) as the supply chain uncertainty due to these events. RFID can reduce deviations events and RFID measurements can be based on these events, such as the number of losses and deviations, as mentioned by Dutta et al. (2007).

Tracking is related to inventory control applied to the coordination of inventory policies by those involved in the supply chain (Nativi \& Lee, 2012). Attaran (2007) predicts that, in the final RFID technology implementation stage, it is possible to process the data collected and use it to adjust supply chain decisions. Dai et al. (2015) indicate that in a minimizing cost model, that supply chain performance can be improved with product traceability.

Standardization has an essential role in global supply chains. Attaran (2007) and Wu et al. (2006) point out that there are standardization opportunities related to International Organization for Standardization (ISO) and Electronic Product Code (EPC)-Global, which include legislation and technological aspects.

Customer satisfaction is characterized by Lim et al. (2013) as the best level in on-time product delivery when providing a service to a customer. Such characterization is confirmed by Lee and Lee (2010).

Integration is pointed out by Attaran (2007) as an attribute that can increase both the Return on Investment (ROI) of technology and the communication among companies. Such integration can increase the economic return as mentioned by Nativi \& Lee (2012). They also state that this information sharing is associated with real-time monitoring, making it possible to reduce unnecessary safety inventories and out-of-stock situations. This attribute potentializes the fluidity within the chain and the alignment between the stakeholders, including the integration of information technology systems.

Cycle time refers to the duration of a process, including waiting times and inventory processing times. This attribute is a measurement of time and as a benefit factor for ROI calculation (Ngai et al., 2007).

Safety includes reliability, integrity, and availability of information (Attaran, 2007). This important attribute is classified as a challenge for technology by Lim et al. (2013).

Sustainability includes environmental, social, and economic aspects. Bose and Yan (2011) selected projects related to this attribute. The attribute assesses the fact that the technology can also help in the reuse and recycling processes as well as for $\mathrm{CO} 2$ reduction. This attribute is related to environmental sustainability as well as social responsibility and business value. Nativi \& Lee (2012) present this attribute as a green supply chain structure. Using the benefits of the tech- 
nology, it was possible to demonstrate, using simulation, a more robust infrastructure, and more significant benefits to the end-users in the market.

Infrastructure is also considered by Wu et al. (2006) as a challenge imposed by the technology. This attribute needs to consider the whole supply chain, especially the one that contains multiple companies.

The attribute technology must be taken into consideration by companies that possess the bar code system and intend to upgrade it as well as companies that do not own an identification system and plan to implement it. Wu et al. (2006) consider this attribute a challenge for RFID implementation, because technology must have limitations, which must be assessed for assuring proper process functioning. Ngai et al. (2007) confirm that notion and put the issue as a lesson learned in the implementation process at the operational level, with tests and validations with hardware and software being required.

The attributes identified in this research expands the key factors suggested by Dai et al. (2015). In their vision, RFID use is motivated basically at two levels of goals. First, enhancement of operational, cost reduction, operational efficiency, and upgrades of asset management capabilities. Second, improving customer satisfaction.

\section{METHOD}

A comprehensive literature raised from Scopus and Web of Science was conducted. The updated contribution (2017-2021) highlighted the attention being given to RFID by researchers and practitioners working in various fields, to show how RFID is influencing multiple disciplinary contexts. RFID papers were searched for and retrieved using the keywords 'Radio Frequency Identification'; 'RFID'; 'logistics' and 'projects. Table 4 presents a summary of the results, including 21 articles with 144 references cited in the following main categories of Web of Science: Business, Computer Science Interdisciplinary Applications, Engineering Multidisciplinary and Management.

Table 4 - Results of the search about RFID.

\begin{tabular}{lc}
\hline Item & Value \\
\hline Number of articles & 21 \\
Number of cited references & 144 \\
Average of citation & 7 \\
h-index & 6 \\
\hline
\end{tabular}

The h-index presented in Table 4 is based on a list of publications in descending order according to the number of citations. Therefore, the h-index of 6 indicates that there are 6 items with 6 citations or more (Hirsch, 2005). 


\subsection{Analytic Hierarchy Process}

AHP is one of the discrete MCDM methods most used in publications (Tramarico et al. 2015) involving both quantitative and qualitative judgements. The relevance of the application of this method in several areas of research such as the allocation of resources and projects justifies this adoption (Durmuşoğlu, 2018; Palcic \& Lalic, 2009; Mahdi \& Alreshaid 2005; Cheng \& Li, 2001; Ramanathan \& Ganesh, 1995)

AHP application includes four steps involving hierarchy construction, pairwise comparison (data collection), and data treatment based on consistency checking, and results (Saaty, 2010). For AHP data treatment, Super Decisions (version 2.2.0) software from the Creative Decisions Foundation (2020) was used.

AHP uses a hierarchy structure to model the complexity and interactions between the various elements involved in a problem. Foundations of AHP include the Fundamental Scale of Absolute Numbers (Saaty, 2010), generating a pairwise comparison matrix $A$, in the sequence, using Linear Algebra concepts, as the eigenvector $(w)$, and eigenvalue ( $\lambda_{\max }$ ) makes it possible to obtain their relative priorities. In AHP, priorities are achieved through application of the Perron-Frobenius theorem (Saaty, 1977), as displayed in (1).

$$
A w=\lambda_{\max } w
$$

The consistency among the comparisons is an important property for A. If $A$ has consistent comparisons, then $a_{i j}=w_{i} / w_{j}$, for $i, j=1,2, \ldots n$, where $\mathrm{n}$ is the order of $A$, and this way, $a_{i j}=a_{i k} a_{k j}$. If $\mathrm{A}$ is not a $100 \%$ consistent matrix, then $\lambda_{\max }>n$. The consistency index, $C I$, calculated by (2), as a measure of the distance between $\lambda_{\max }$ and $n$ :

$$
C I=\left(\lambda ?_{\max }-n\right) /(n-1)
$$

$C R$, obtained with (3), also considers a random index $R I$, associated to $n$. If $C R$ is greater than 0.10 , a review on the comparisons may be necessary (Saaty, 2010).

$$
C R=C I / R I
$$

Absolute measurement, also known as "rating", alternatives are compared with standard levels, instead of pairwise comparisons (Saaty, 1986). In this research, it was evaluated using the judgments for criteria and ratings for alternatives.

\subsection{Case description and identification of the experts}

The case study included nine companies in the aerospace sector and, together, represents $98 \%$ of the revenue and $90 \%$ of the jobs created in the Brazilian aerospace supply network, based on the Brazilian Aerospace Industries Association (AIAB). The sample included Brazilian, Russian, 
and French parts manufacturers, aircraft manufacturers, helicopters manufacture, and military companies. The experts and executives interviewed led logistics projects, operations, and technology implementation in the Brazilian aeronautical companies. The profile of the participants is presented in Table 5.

Table 5 - Profile of the participants.

\begin{tabular}{lccc}
\hline Function/Experience & up to 5 years & up to 10 years & more than 10 years \\
\hline Engineer /Expert & 0 & 3 & 2 \\
Supervisor & 1 & 3 & 3 \\
Manager/Director & 1 & 3 & 7 \\
\hline
\end{tabular}

The total 23 respondents were interviewed, $52 \%$ of which has more than ten years as executives.

\subsection{Definition of objective and construction of hierarchy}

The objective of the model was to "Project's prioritization" and the purpose was to state the decision problem. This objective resulted in a proper decision-making in which several aspects were considered, including the criteria based on RFID projects attributes identified in the literature review Section 2.

The set of criteria are defined such as cost, customer satisfaction, cycle time, information, operational efficiency, quality, safety, sustainability, technology. The set of sub criteria are defined such as availability, integrity, reliability, business value, $\mathrm{CO} 2$ reduction, reuse/recycling, social responsibility, integration, management/tracking, visibility, infrastructure, standardization, technology development/updating.

The set of alternatives are defined such as project (P1) tracking in the supply chain, (P2) automatic inventory, (P3) components and assets identification, $(\mathrm{P} 4)$ reverse logistics, (P5) Decision support/ predictive logistics, (P6) Pallets receiving, (P7) Industrial process automation - income inspection, (P8) Industrial process automation - storage, (P9) Industrial process automation picking, (P10) Industrial process automation - expedition, (P11) Automatic resupplying, (P12) Monitoring items that are inside transportation vehicles, (P13) Data transfer by RFID, (P14) Recycling process management, (P15) Monitoring of high value items. The criteria and alternatives were validated by the experts.

Hierarchy structure is a form that supports the thought with regards to what a problem is. A typical decision problem requires choosing the best solution with respect to a set of criteria. The hierarchy is constructed from the top down. The objective and criteria and sub criteria were grouped, resulting in a hierarchy to projects prioritization (Figure 4).

\section{FINDINGS}

In AHP, paired comparisons are made with judgements using numerical values taken from the AHP Fundamental Scale of Absolute Numbers, which indicates by quantity how important or 


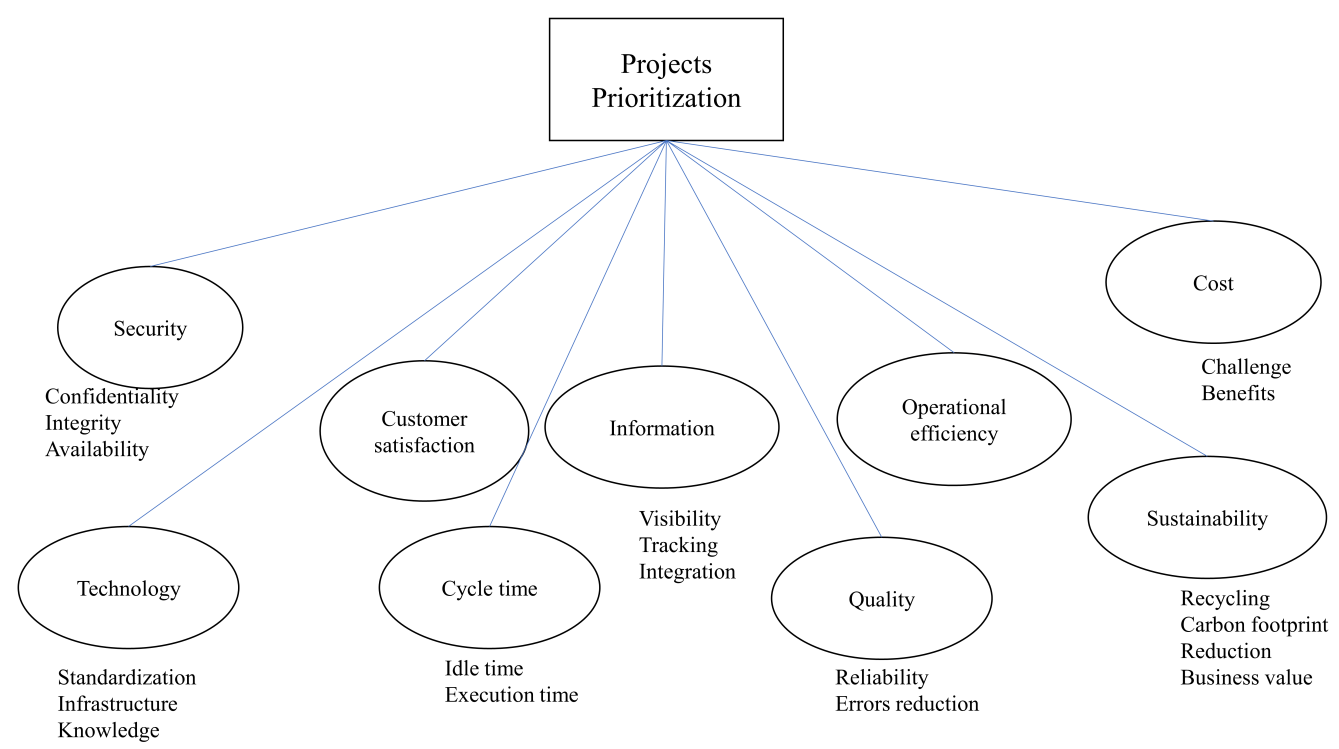

Figure 4 - Hierarchy for projects prioritization.

dominant one element is over another element with respect to each criterion or property to which they are compared (Saaty, 2008).

The ranking of RFID projects related to logistics is based on Figure 4. From the data collected, the first step is to compare the elements in each level in pairs, the geometric mean, Equation 4, was used to perform the synthesis.

$$
f\left(x_{1}, x_{2}, \ldots, x_{n}\right)=\sqrt[n]{x_{1}} \cdot x_{2} \cdot(\ldots) \cdot x_{n}
$$

The pairwise judgments for cost, customer satisfaction, cycle, information, operational efficiency, quality, safety, sustainability, and technology criteria are shown in Table 6.

Table 6 - Synthesized matrix of attributes.

\begin{tabular}{llllllllll}
\hline & CO & CS & CY & IN & OE & QU & SA & SU & TE \\
\hline Cost (CO) & 1 & 0.40 & 1.01 & 1.54 & 1.35 & 0.51 & 0.32 & 1.83 & 1.25 \\
Customer Satisfaction (CS) & 2.50 & 1 & 2.88 & 3.32 & 3.01 & 1.38 & 0.49 & 3.23 & 3.50 \\
Cycle (CY) & 0.99 & 0.35 & 1 & 1 & 0.86 & 0.53 & 0.33 & 1.70 & 1.31 \\
Information (IN) & 0.65 & 0.30 & 1 & 1 & 0.77 & 0.34 & 0.43 & 1.78 & 0.94 \\
Operational Efficiency (OE) & 0.74 & 0.33 & 1.17 & 1.29 & 1 & 0.48 & 0.3 & 1.91 & 1.48 \\
Quality (QU) & 1.96 & 0.73 & 1.89 & 2.95 & 2.08 & 1 & 0.89 & 3.62 & 2.28 \\
Safety (SA) & 3.10 & 2.02 & 3.04 & 2.35 & 3.34 & 1.13 & 1 & 6.38 & 5.26 \\
Sustainability (SU) & 0.55 & 0.31 & 0.59 & 0.56 & 0.52 & 0.28 & 0.16 & 1 & 0.90 \\
Technology (TE) & 0.80 & 0.29 & 0.76 & 1.06 & 0.68 & 0.44 & 0.19 & 1.12 & 1 \\
\hline
\end{tabular}


The consistency can be considered as valid when the highest consistency index equals 0.02 . The synthesis of the safety attribute is presented in Table 7.

Table 7 - Synthesized matrix of safety.

\begin{tabular}{lccc}
\hline & Availability & Integrity & Reliability \\
\hline Availability & 1 & 0.38 & 0.55 \\
Integrity & 2.61 & 1 & 0.78 \\
Reliability & 1.83 & 1.28 & 1 \\
\hline
\end{tabular}

The synthesis of the sustainability attribute is presented in Table 8 .

Table 8 - Synthesized matrix of sustainability.

\begin{tabular}{lcccc}
\hline & Business value & CO2 reduction & Reuse/ recycling & Social responsibility \\
\hline Business value & 1 & 1.53 & 2.31 & 1.40 \\
CO2 reduction & 0.65 & 1 & 0.68 & 0.66 \\
Reuse/recycling & 0.43 & 1.48 & 1 & 0.48 \\
Social responsibility & 0.71 & 1.51 & 2.09 & 1 \\
\hline
\end{tabular}

The synthesis of the information attribute is presented in Table 9.

Table 9 - Synthesized matrix of information.

\begin{tabular}{lccc}
\hline & Integration & Management/ Tracking & Visibility \\
\hline Integration & 1 & 0.48 & 1.85 \\
Management/Tracking & 2.09 & 1 & 1.7 \\
Visibility & 0.54 & 0.59 & 1 \\
\hline
\end{tabular}

The synthesis of the technology attribute is presented in Table 10 .

Table 10 - Synthesized matrix of technology.

\begin{tabular}{lccc}
\hline & Infrastructure & Standardization & Technology development/updating \\
\hline Infrastructure & 1 & 0.94 & 0.75 \\
Standardization & 1.06 & 1 & 0.71 \\
Technology development/updating & 1.34 & 1.41 & 1 \\
\hline
\end{tabular}

After achieving the judgments for attributes, the priorities were calculated. As shown in the results displayed in Table 11, the Brazilian aerospace supply network has a high level of concern with safety, customer satisfaction, and quality. These results stem from the industry's insertion in a globally competitive market, with high levels of technology, long product development cycle, risks associated with aircraft operations, and strict product certification standards.

The absolute model is used to rank independent alternatives one at a time in terms of rating priorities for each of the criteria. Table 12 presents the priority levels of importance set for the project's assessment alternatives 
Table 11 - Attributes priorities.

\begin{tabular}{lc}
\hline Attribute & Normalization \\
\hline Cost & 0.082 \\
Customer satisfaction & 0.191 \\
Cycle & 0.073 \\
Information & 0.066 \\
Operational efficiency & 0.076 \\
Quality & 0.160 \\
Safety & 0.250 \\
Sustainability & 0.044 \\
Technology & 0.057 \\
\hline
\end{tabular}

Table 12 - Levels for alternative performances and their importance.

\begin{tabular}{lc}
\hline Level & Importance \\
\hline Absolute & 5 \\
Very large & 4 \\
Large & 3 \\
Small & 2 \\
No & 1 \\
\hline
\end{tabular}

The alternatives are summarized in Table 13.

The results are presented in Table 14. 
Table 13 - Synthesis of the alternatives.

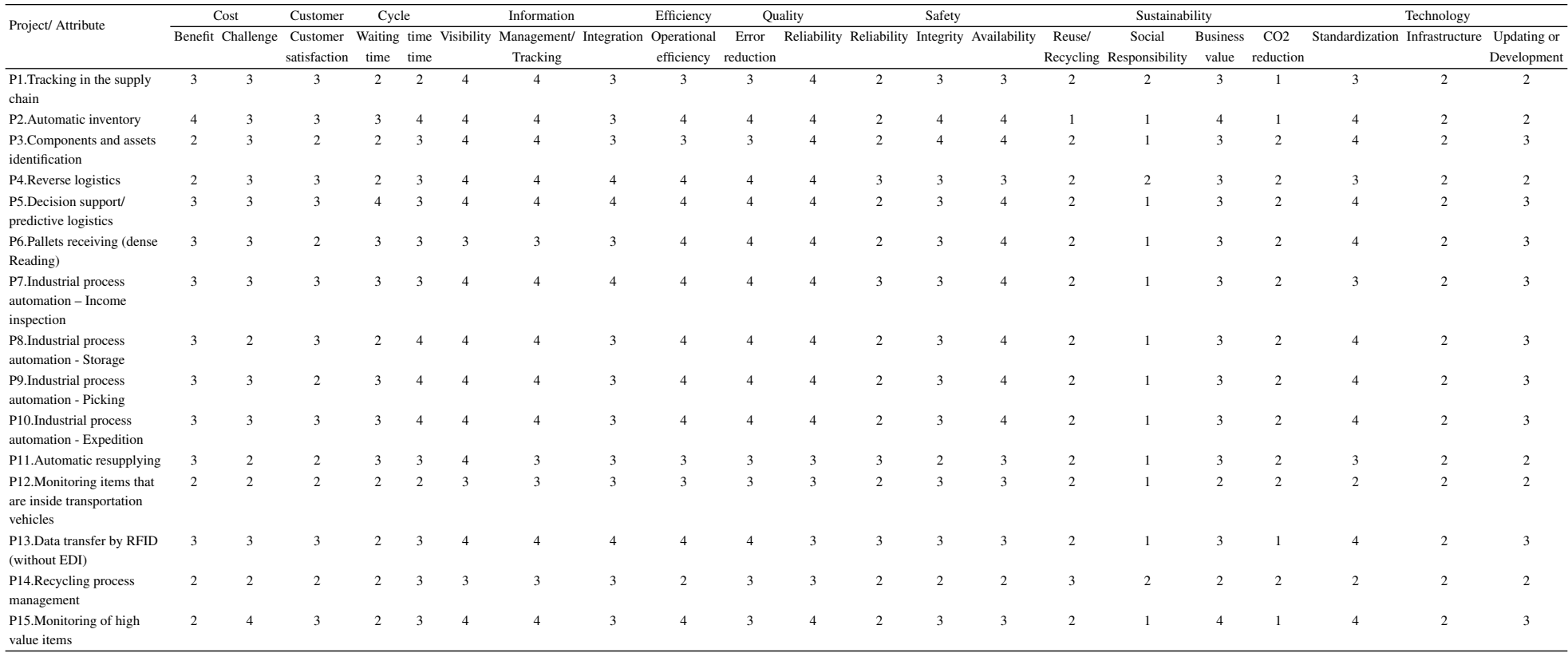


Table 14 - Classification of RFID projects.

\begin{tabular}{llccc}
\hline Project & Normalized & Idealized & Ranking \\
\hline P2 & Automatic inventory & 0.0766 & 1,000 & 1 \\
P7 & Industrial processes automation - Income inspection & 0.0749 & 0.978 & 2 \\
P10 & Industrial processes automation - Expedition & 0.0734 & 0.9588 & 3 \\
P5 & Decision support/ Predictive logistics & 0.0731 & 0.9548 & 4 \\
P8 & Industrial processes automation - storage & 0.0717 & 0.9371 & 5 \\
P4 & Reverse logistics & 0.0717 & 0.9362 & 6 \\
P13 & Data transfer by RFID (without EDI) & 0.0703 & 0.9179 & 7 \\
P15 & High value items monitoring & 0.0691 & 0.9031 & 8 \\
P9 & Industrial processes automation - Picking & 0.0683 & 0.8919 & 9 \\
P6 & Pallets receiving (dense reading) & 0.0656 & 0.8574 & 10 \\
P3 & Components and assets identification & 0.0646 & 0.8437 & 11 \\
P1 & Supply chain tracking & 0.0645 & 0.8431 & 12 \\
P11 & Automatic resupply & 0.0564 & 0.7366 & 13 \\
P12 & Monitoring of items inside transportation vehicle & 0.0519 & 0.6783 & 14 \\
P14 & Recycling process management & 0.0479 & 0.626 & 15 \\
\hline
\end{tabular}

\section{DISCUSSION AND CONCLUSIONS}

Automatic inventory is the project with the most significant relevance for the interviewees. Characteristics that can explain this result is the labor-intensity of the activity, which requires a large number of people to carry out this procedure throughout the year. Besides, maintaining a high level of accuracy to assure resource availability and their acquisition value is critical.

The second and third projects of highest importance are related to the receiving inspection and expedition stages of automation. This consideration reflects the importance of assuring the entrance and exit with a larger index of certainty to avoid inventory problems, returned items, and customers' and suppliers' demand satisfaction. The supply chain tracking project held the tenth position, and the inventory project occupied the second position in the rank.

The sensitivity analysis carried out of the three attributes that presented largest relevance, so could assess the robustness of the results. In Figure 5, the vertical line represents the weight for safety attribute equal to 0.25039 . The sensitivity analysis demonstrated that in the margins of the result equal to 0.25039 there is no change in the ranking of the first placed attributes. The change of the first place occurs only when changes to $\sim 0.85$.

In Figure 6, the vertical line represents the weight of customer satisfaction attribute equal to 0.1987 . The change in such quality does not change the first place in the ranking. There are more significant changes in the rankings with projects P3, P6, and P9 that are negatively affected by the increase of such attribute, as opposed to Project P1, that is benefitted by this behavior.

In Figure 7, the vertical line represents the weight of customer satisfaction attribute equal to 0.15997. This attribute also does not show a considerable variation around the real region. Project 

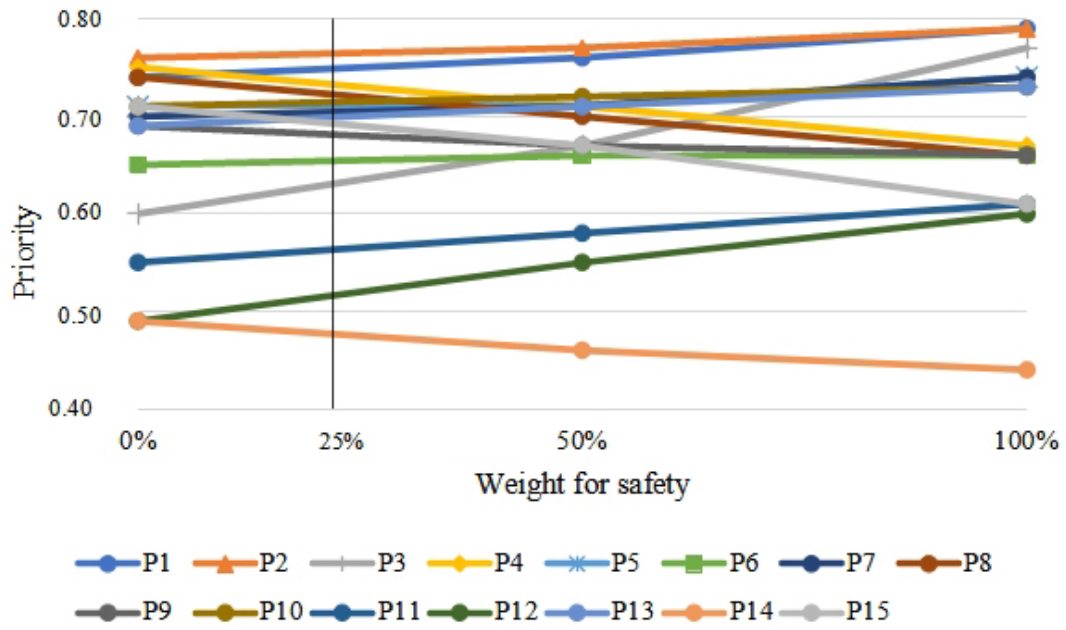

Figure 5 - Sensitivity analysis of safety.

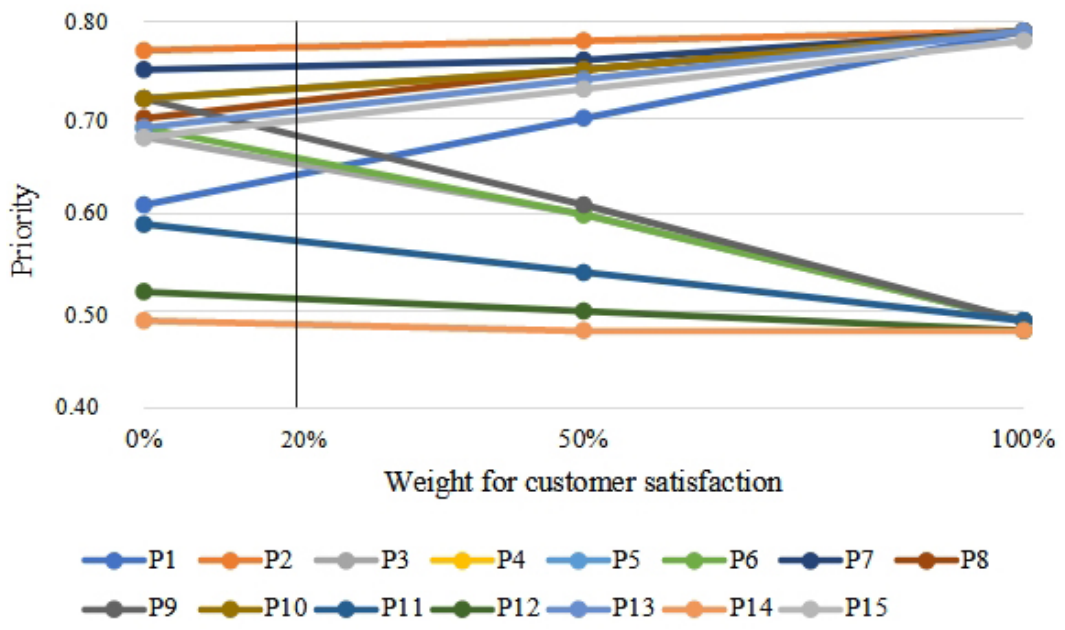

Figure 6 - Sensitivity of customer satisfaction.

P13 loses positions in the classification with the increase of such attribute, as opposed to projects $\mathrm{P} 6$ and $\mathrm{P} 15$.

The results are also assessed as a function of the interviewee (Figure 8).

Nevertheless, the prioritization of the attribute's safety, customer satisfaction, and quality, in all groups, encompassed $55 \%$ to $65 \%$. The impact in the project's classification, with such variation, is shown in Figure 9.

The projects legend (Figure 5, Figure 6, Figure 7 and Figure 9) is presented in Table 15. 


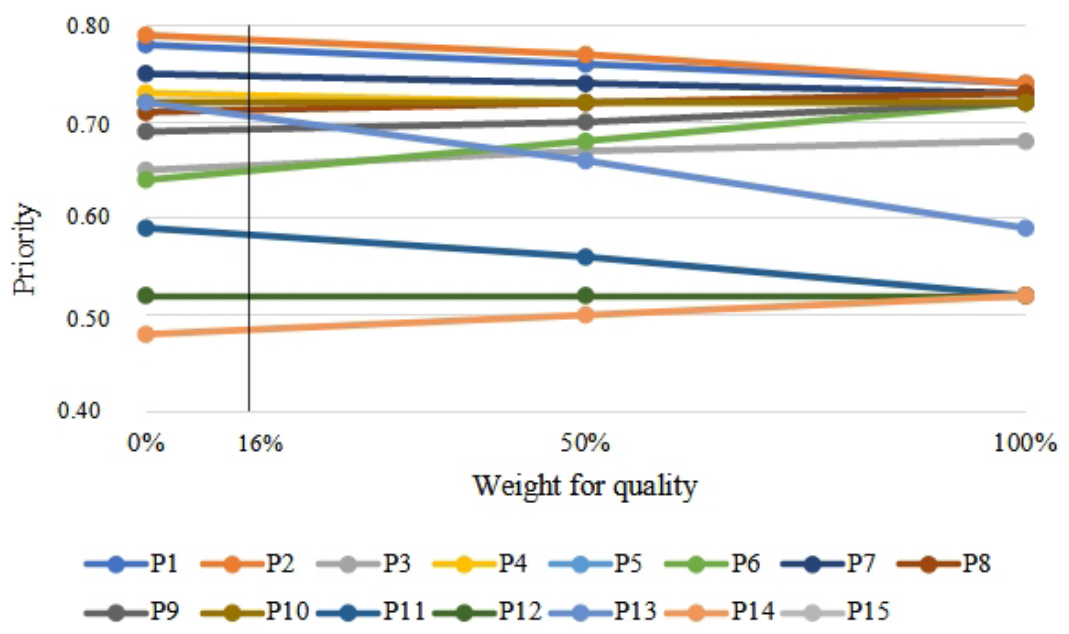

Figure 7 - Sensitivity of quality.

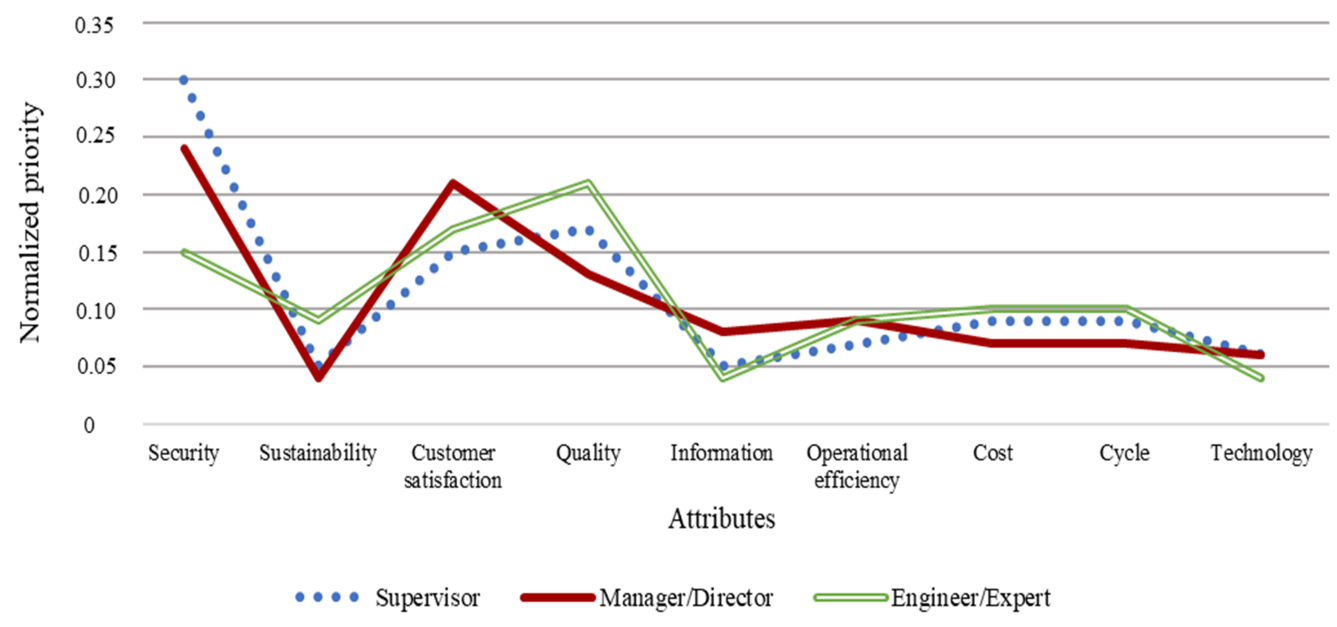

Figure 8 - Prioritization of attributes per function.

Therefore, there are differences in the views of the different groups. The engineers/experts prioritized the projects related to supply chain tracking (P1), automatic inventory (P2), and the use of technology to decision support/predictive logistics (P5). The Supervisors prioritized high-value items monitoring (P15), process automation in the material expedition (P10), and process automation in the storage (P8). In the view of managers/directors, the higher priority should be given to inventory (P2), assets, and components identification (P3) and also in the high-value item monitoring (P15).

In conclusion that such variation is caused by the difference in levels of understanding regarding the real contribution of the technology within the logistics processes. Another plausible expla- 


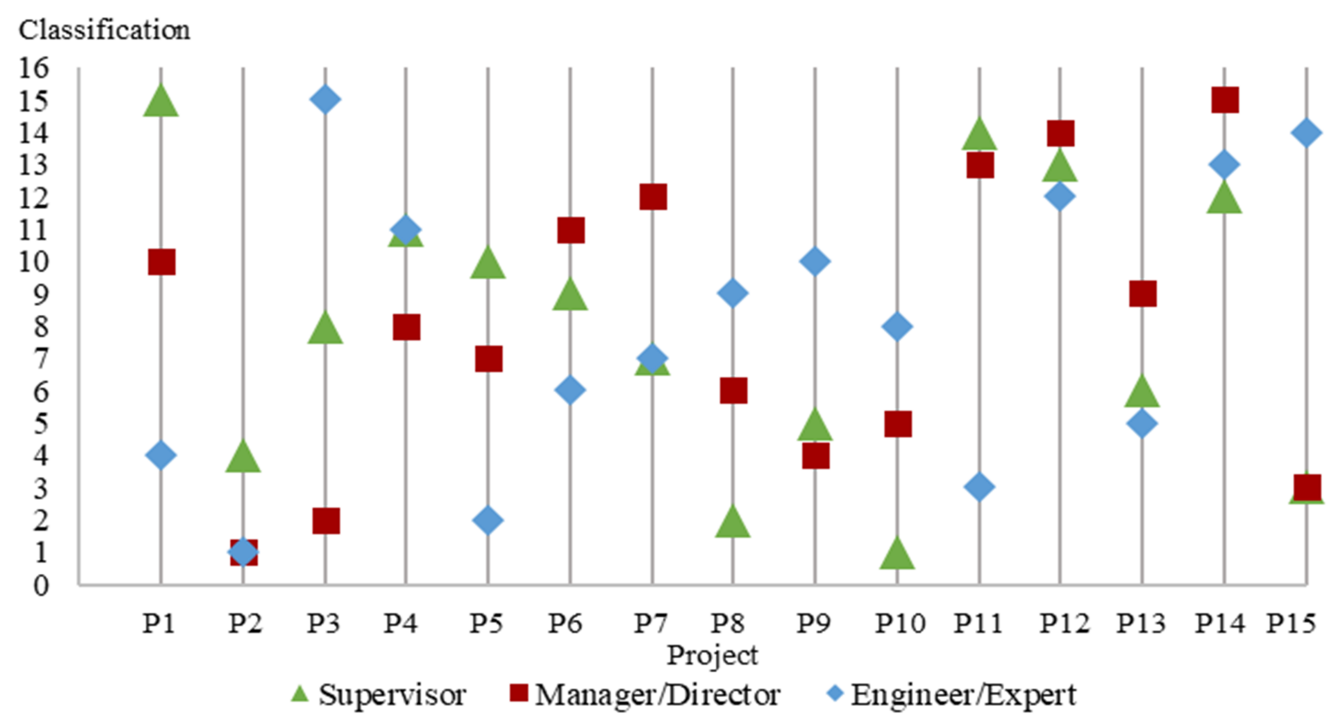

Figure 9 - Projects classification per function.

Table 15 - Projects description.

\begin{tabular}{ll}
\hline Project & \multicolumn{1}{c}{ Description } \\
\hline P1 & Supply chain tracking \\
P2 & Automatic inventory \\
P3 & Components and assets identification \\
P4 & Reverse logistics \\
P5 & Decision support/ Predictive logistics \\
P6 & Pallets receiving (dense reading) \\
P7 & Industrial processes automation - Income inspection \\
P8 & Industrial processes automation - storage \\
P9 & Industrial processes automation - Picking \\
P10 & Industrial processes automation - Expedition \\
P11 & Automatic resupply \\
P12 & Monitoring of items inside transportation vehicle \\
P13 & Data transfer by RFID (without EDI) \\
P14 & Recycling process management \\
P15 & High value items monitoring \\
\hline
\end{tabular}

nation is the differences in concerns and work profiles, which tend to bias the assessments and judgements

The logistics projects prioritized in the Brazilian aerospace industry are automatic inventory, automation of industrial processes - income inspection and expedition. The Findings evidence that Analytic Hierarchic Structure supports assessment of Logistic projects to the aerospace sector. 
The project that supposedly would be number one occupied the position number 10 in the classification. Therefore, the method presented is a tool to make more robust decision processes for classifying RFID logistics projects in the Brazilian aeronautics industry.

Considering only the industrial processes automation projects, the classification presented is exactly inverse to the number of applications presented by Lim et al. (2013). Notably, operational projects, i.e., those that have a physical impact in the processes, had better positioning in the classification if compared with those related to process information and management. This indicates a high level of process control or process inefficiency. It can also be concluded that there is a concern about the technology issue. This concern is pointed out by Zhou (2009) and confirmed with project assessment according to this attribute. The interviewees do not consider the technology with fewer applications for issues related to Sustainability.

The research strategy helped synthesize the results and develop a consolidated view of the projects. These activities would be extremely laborious and time-consuming if they were performed using alignment meetings. The variation and divergence of opinions about project classification would make it a protracted enterprise.

The model presented can be applied to the evaluation of other projects with overarching characteristics similar to that of RFID, applied to the logistics of the Brazilian aeronautics industry. Generally speaking, the low level of understanding about the technology and its benefits is noticeable despite familiarity with the technology. Besides, the use of the technology is still minimal. Both factors call for further investigation in this area and make this research relevant, increasing the understanding of the technology and its use.

\section{References}

[1] AIRBUS. 2014. Radio frequency identification (RFID) - Airbus business radar. Available at: http://www.airbus.com/fileadmin/media_gallery/files/brochures_publications/ FAST_magazine/FAST47_8-rfid.pdf. Accessed in November 1st, 2014.

[2] Ataebiz. 2010. ATA e-Business Program 2010. ATA E-BIZ. Available at: http://www. ataebiz.org/forum/2010 \_ata \_e-biz \_forum/RFID \_Combined $\backslash \_2010$.jpg. Accessed in November 1st, 2014.

[3] AtTaran M. 2007. RFID: an enabler of supply chain operations. Supply Chain Management: An International Journal, 12(4): 249-257.

[4] BhatTACHARYA M. 2012. Impact of RFID on the retail value chain: An exploratory study using a mixed method approach. Journal of technology management \& innovation, 7(4): 36-49.

[5] Bittencourt R, Valente AM \& Lobo E. 2018. Introducing a new support model for access control of road cargo vehicles at Brazilian ports through Radio Frequency Identification Technology (RFID). urbe. Revista Brasileira de Gestão Urbana, 10(3): 576-587. 
[6] Bottani E, Bertolini M, Rizzi A \& Romagnoli G. 2017. Monitoring on-shelf availability, out-of-stock and product freshness through RFID in the fresh food supply chain. International Journal of RF Technologies, 8(1-2): 33-55.

[7] Bose I \& YAn S. 2011. The green potential of RFID projects: a case-based analysis. It Professional, 13(1): 41-47.

[8] Cilloni G, Leporati R, Rizzi A \& Romagnoli G. 2019. State of the art of item-level rfid deployments in fashion and apparel retail. International Journal of $R F$ Technologies, 10(3-4): 65-88.

[9] Chen Q, Adey BT, HaAs C \& Hal DM. 2020. Using look-ahead plans to improve material flow processes on construction projects when using BIM and RFID technologies. Construction Innovation, 20(3): 471-508.

[10] Cheng EW \& Li H. 2001. Information priority-setting for better resource allocation using analytic hierarchy process (AHP). Information Management \& Computer Security, 9(2): 61-70.

[11] ChOng AYL \& CHAN FT. 2012. Structural equation modeling for multi-stage analysis on Radio Frequency Identification (RFID) diffusion in the health care industry. Expert Systems with Applications, 39(10): 8645-8654.

[12] Chong AYL, Liu MJ, Luo J \& Keng-Boon O. 2015. Predicting RFID adoption in healthcare supply chain from the perspectives of users. International Journal of Production Economics, 159: 66-75.

[13] Creative Decisions Foundation. 2020. Super Decisions, version 2.2.0. Available at: http://http://www.superdecisions.com/. Accessed in June 4th, 2020.

[14] DAI H \& TSENG MM. 2012. The impacts of RFID implementation on reducing inventory inaccuracy in a multi-stage supply chain. International Journal of Production Economics, 139(2): 634-641.

[15] DAI H, GE L \& ZHOU W. 2015. A design method for supply chain traceability systems with aligned interests. International Journal of Production Economics, 170: 14-24.

[16] De Kok AG, Van Donselaar KH \& VAn Woensel T. 2008. A break-even analysis of RFID technology for inventory sensitive to shrinkage. International Journal of Production Economics, 112(2): 521-531.

[17] De Marco A, Cagliano AC, Nervo ML \& Rafele C. 2012. Using System Dynamics to assess the impact of RFID technology on retail operations. International journal of production economics, 135(1): 333-344.

[18] DuRmuşoĞLU ZDU. 2018. Assessment of techno-entrepreneurship projects by using Analytical Hierarchy Process (AHP). Technology in Society, 54: 41-46. 
[19] DutTa A, LeE HL \& Whang S. 2007. RFID and operations management: technology, value, and incentives. Production and operations management, 16(5): 646-655.

[20] FAn T, TAO F, Deng S \& Li S. 2015. Impact of RFID technology on supply chain decisions with inventory inaccuracies. International Journal of Production Economics, 159: $117-125$.

[21] GAUKLER GM. 2010. Item-level RFID in a retail supply chain with stock-out-based substitution. IEEE Transactions on Industrial Informatics, 7(2): 362-370.

[22] GAUKLER GM. 2011. RFID tag cost sharing in the retail supply chain. Journal of Organizational Computing and Electronic Commerce, 21(4): 315-331.

[23] Hardgrave BC, Aloysius JA \& Goyal S. 2013. RFID-enabled visibility and retail inventory record inaccuracy: experiments in the field. Production and Operations Management, 22(4): 843-856.

[24] HAZEN BT \& BYRD TA. 2012. Toward creating competitive advantage with logistics information technology. International Journal of Physical Distribution \& Logistics Management, 42: 8-35.

[25] Hazen BT, Boone CA, Ezell JD \& Jones-Farmer LA. 2014. Data quality for data science, predictive analytics, and big data in supply chain management: an introduction to the problem and suggestions for research and applications. International Journal of Production Economics, 154: 72-80.

[26] HiRsCH JE, 2005. An index to quantify an individual's scientific research output. Proceedings of the National Academy of Sciences of the United States of America, 102 (46): 16569-16572.

[27] Hellström D \& Wiberg M. 2010. Improving inventory accuracy using RFID technology: a case study. Assembly Automation, 30(4): 345-351.

[28] Hunt VD, Puglia A \& Puglia M. 2007. RFID: a guide to radio frequency identification. John Wiley \& Sons, New jersey, NJ.

[29] KÖKSAlan MM, WalleniUs J \& Zionts S. 2011. Multiple criteria decision making: from early history to the 21st century. World Scientific, New jersey, NJ.

[30] LeE YM, Cheng F \& LEUng YT. 2004. Exploring the impact of RFID on supply chain dynamics in Proceedings of the 2004 Winter Simulation Conference, IEEE, 2: 1145-1152.

[31] LEE CK \& ChAn TM. 2009. Development of RFID-based reverse logistics system. Expert Systems with Applications, 36(5): 9299-9307.

[32] LEE I. \& Lee BC. 2010. An investment evaluation of supply chain RFID technologies: A normative modeling approach. International Journal of Production Economics, 125(2): 313-323. 
[33] LEE H \& ÖZER Ö. 2007). Unlocking the value of RFID. Production and operations management, 16(1): 40-64.

[34] LEE CP \& SHIM JP. 2007. An exploratory study of radio frequency identification (RFID) adoption in the healthcare industry. European Journal of Information Systems, 16(6): 712724.

[35] Li CZ, Zhong RY, Xue F, Xu G, Chen K, Huang GG \& Shen GQ. 2017. Integrating RFID and BIM technologies for mitigating risks and improving schedule performance of prefabricated house construction. Journal of Cleaner Production, 165: 1048-1062.

[36] Lim MK, BAHr W \& LEUng SC. 2013. RFID in the warehouse: A literature analysis (1995-2010) of its applications, benefits, challenges and future trends. International Journal of Production Economics, 145(1): 409-430.

[37] LiN CS, CHEN LS \& HSU CC. 2011. An innovative approach for RFID product functions development. Expert Systems with Applications, 38(12): 15523-15533.

[38] Lorentz H \& Ghauri PN. 2010. Demand supply network opportunity development processes in emerging markets: positioning for strategy realization in Russia. Industrial Marketing Management, 39(2): 240-251.

[39] LYU J, ChAng SY \& CHEN TL. 2009. Integrating RFID with quality assurance system - Framework and applications. Expert Systems with Applications, 36: 10877-10882.

[40] Mahdi IM \& AlReshaid K. 2005. Decision support system for selecting the proper project delivery method using analytical hierarchy process (AHP). International journal of project management, 23(7): 564-572.

[41] Moatari-Kazerouni A \& Bendavid Y. 2017. Improving logistics processes of surgical instruments: case of RFID technology. Business Process Management Journal. 23(2): 448-466.

[42] Moon S, Xu S, Hou L, Wu C, WAng X \& TAM VW. 2018. RFID-aided tracking system to improve work efficiency of scaffold supplier: Stock management in Australasian supply chain. Journal of Construction Engineering and Management, 144(2): 04017115.

[43] Müller-Seitz G, Dautzenberg K, Creusen, U \& Stromereder C. 2009. Customer acceptance of RFID technology: Evidence from the German electronic retail sector. Journal of retailing and consumer services, 16(1): 31-39.

[44] Muniz Jr. J, Hong J, Oliveira, S, Wintersberger D \& Popadiuk S. 2019. Knowledge sharing in the automotive sector: a comparative study of chinese and brazilian firms. Production, 29, e20180084. 
[45] Ngai EWT, Cheng TCE, Lai KH, Chai PYF, ChoiYS. \& Sin, RKY. 2007. Development of an RFID-based traceability system: experiences and lessons learned from an aircraft engineering company. Production and operations management, 16(5): 554-568.

[46] Ngai EWT, Moon KK, Riggins FJ \& CANDACE YY. 2008. RFID research: An academic literature review (1995-2005) and future research directions. International Journal of Production Economics, 112(2): 510-520.

[47] NASSAR V \& VIEIRA MLH. 2017. O compartilhamento de informações no transporte público com as tecnologias RFID e NFC: uma proposta de aplicação. urbe. Revista Brasileira de Gestão Urbana, 9(2): 327-340.

[48] NATIVi JJ \& LEE S. 2012. Impact of RFID information-sharing strategies on a decentralized supply chain with reverse logistics operations. International Journal of Production Economics, 136(2): 366-377.

[49] Oner M, Ustundag A \& BudaK A. 2017. An RFID-based tracking system for denim production processes. The International Journal of Advanced Manufacturing Technology, 90(1-4): 591-604.

[50] Ozguven EE \& OzBAy K. 2015. An RFID-based inventory management framework for emergency relief operations. Transportation research part C: emerging technologies, 57: 166-187.

[51] Pagell M, Katz JP \& Chwen S. 2005. The importance of national culture in operation management research. International Journal of Operations \& Production Management, 25(4): 371-94.

[52] PAlciC I \& LAliC B. 2009. Analytical Hierarchy Process as a tool for selecting and evaluating projects. International Journal of Simulation Modelling, 8(1): 16-26.

[53] PRASAD S \& BABBAR S. 2000. International operations management research. Journal of operations management, 18(2): 209-247.

[54] PRASAD S \& TATA J. 2010. Micro-enterprise supply chain management in developing countries. Journal of Advances in Management Research, 7(1):8-31.

[55] Ramanathan R \& Ganesh LS. 1995. Using AHP for resource allocation problems. European Journal of Operational Research, 80(2), 410-417.

[56] RAY BR, AbAwAJY J \& Chowdhury M. 2014. Scalable RFID security framework and protocol supporting Internet of Things. Computer Networks, 67: 89-103.

[57] Roberti M. 2014. Item-level RFID adoption in retail gathers momentum. RFIDJ. Available at: https://www.rfidjournal.com/ item-level-rfid-adoption-in-retail-gathers-momentum. Accessed in November 1st, 2014 
[58] ReKiK Y, SAhin E \& DAllery Y. 2008. Analysis of the impact of the RFID technology on reducing product misplacement errors at retail stores. International Journal of Production Economics, 112(1): 264-278.

[59] REN Y \& LI H. 2018. Building materials management system based on RFID technology. International Journal of RF Technologies, 9(1-2):63-74.

[60] SAATY TL. 1977. A scaling method for priorities in hierarchical structures. Journal of Mathematical Psychology, 15(3): 234-281.

[61] SaAty T L. 1986. Absolute and relative measurement with the AHP. The most livable cities in the United States. Socio-Economic Planning Sciences, 20(6): 327-331.

[62] SAATY TL. 2008. Decision making with the analytic hierarchy process. International Journal Services Sciences, 1(1): 83-98

[63] SAATY TL. 2010. Mathematical principles of decision making (Principia mathematica decernendi). RWS publications, Pittsburgh.

[64] SARAC A, Absi N \& DAUZÈre-PÉrÈs S. 2010. A literature review on the impact of RFID technologies on supply chain management. International journal of production economics, 128(1): 77-95.

[65] Senauer B \& Seltzer J. 2010. The changing face of food retailing. Choices Magazine and the Agricultural and Applied Economics Association, 25(4): 1-5.

[66] Shin S \& EKSIOGLU B. 2015. An empirical study of RFID productivity in the US retail supply chain. International Journal of Production Economics, 163: 89-96.

[67] SHIN S \& TUCCI JE. 2015. Wal-Marts dilemma in the 21st century: sales growth vs. inventory growth. Journal of Applied Business Research, 31(1): 37-46.

[68] Shingijutsu. 2014. Kanban System (Just-in-time). Available at: http://www.shingijutsu/ global.com/en/justintime.html. Accessed in November 1st, 2014.

[69] SipAhi S \& TIMOR M. 2010. The analytic hierarchy process and analytic network process: an overview of applications. Management Decision, 48(5): 775-808.

[70] Thiel D, Hovelaque V \& Le HoA VT. 2010. Impact of inventory inaccuracy on service-level quality in $(\mathrm{Q}, \mathrm{R})$ continuous-review lost-sales inventory models. International Journal of Production Economics, 123(2): 301-311.

[71] Thiesse F, Stanke T, Schmitt P \& Fleisch E. 2011. The rise of the "nextgeneration bar code": an international RFID adoption study. Supply Chain Management: An International Journal, 16(5): 328-345. 
[72] Tramarico CL, Mizuno D, Salomon VAP \& Marins FAS. 2015. Analytic hierarchy process and supply chain management: A bibliometric study. Procedia Computer Science, 55: 441-450.

[73] TRApPey AJ, TRAPPEy CV \& WU CR. 2010. Genetic algorithm dynamic performance evaluation for RFID reverse logistic management. Expert Systems with Applications, 37(11): 7329-7335.

[74] TREBAR M, LOtRič M \& Fonda I. 2015. Use of RFID temperature monitoring to test and improve fish packing methods in styrofoam boxes. Journal of Food Engineering, 159: 66-75.

[75] Tsai MC, LEE W \& WU HC. 2010. Determinants of RFID adoption intention: Evidence from Taiwanese retail chains. Information \& Management, 47(5-6): 255-261.

[76] Ustundag A \& TAnyas M. 2009. The impacts of radio frequency identification (RFID) technology on supply chain costs. Transportation Research Part E: Logistics and Transportation Review, 45(1): 29-38.

[77] VÉronneau S \& RoY J. 2009. RFID benefits, costs, and possibilities: The economical analysis of RFID deployment in a cruise corporation global service supply chain. International Journal of Production Economics, 122 (2): 692-702.

[78] WAMBA SF \& NGAI EW. 2012. Importance of the relative advantage of RFID as enabler of asset management in the healthcare: results from a Delphi study. In 2012 45th Hawaii International Conference on System Sciences, IEEE, 2879-2889.

[79] WANG SJ, LIU SF \& WANG WL. 2008. The simulated impact of RFID-enabled supply chain on pull-based inventory replenishment in TFT-LCD industry. International Journal of Production Economics, 112(2): 570-586.

[80] Wasserman E. 2007. Airbus grand plans for RFID, RFID Journal, October 1.

[81] Whitaker J, Mithas S \& Krishnan MS. 2007. A field study of RFID deployment and return expectations. Production and Operations Management, 16(5): 599-612.

[82] Wu NC, Nystrom MA, Lin TR \& YU HU. 2006. Challenges to global RFID adoption. Technovation, 26: 1317-1323.

[83] YIN SY, TSERng HP, WANG JC \& TSAI SC. 2009. Developing a precast production management system using RFID technology. Automation in construction, 18(5): 677-691.

[84] ZHOU W. 2009. RFID and item-level information visibility. European Journal of Operational Research, 198(1): 252-258.

[85] Zhu X, Mukhopadhyay SK \& Kurata H. 2012. A review of RFID technology and its managerial applications in different industries. Journal of Engineering and Technology Management, 29(1): 152-167. 


\section{How to cite}

Castro Ji, Muniz JR. J, Bernardes E and Tramarico CL. 2021. Logistics projects based on radio frequency identification: multi-criteria assessment of brazilian aircraft industry. Pesquisa Operacional, 41: e244928. doi: 10.1590/0101-7438.2021.041.00244928. 